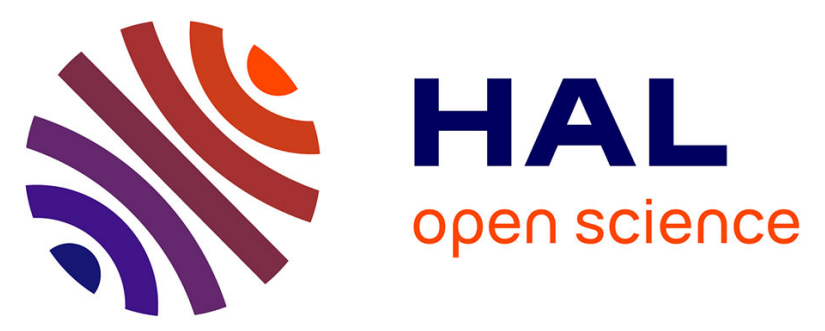

\title{
Tackling material dependency in sustainability transition: rationales and insights from the agriculture sector \\ Luigi Pellizzoni, Laura Centemeri
}

\section{- To cite this version:}

Luigi Pellizzoni, Laura Centemeri. Tackling material dependency in sustainability transition: rationales and insights from the agriculture sector. Journal of Environmental Policy and Planning, In press, 10.1080/1523908x.2021.2022467 . hal-03511854

\author{
HAL Id: hal-03511854 \\ https://hal.science/hal-03511854
}

Submitted on 5 Jan 2022

HAL is a multi-disciplinary open access archive for the deposit and dissemination of scientific research documents, whether they are published or not. The documents may come from teaching and research institutions in France or abroad, or from public or private research centers.
L'archive ouverte pluridisciplinaire HAL, est destinée au dépôt et à la diffusion de documents scientifiques de niveau recherche, publiés ou non, émanant des établissements d'enseignement et de recherche français ou étrangers, des laboratoires publics ou privés. 
To cite this article:

Luigi Pellizzoni \& Laura Centemeri (2022) Tackling material dependency in sustainability transition: rationales and insights from the agriculture sector, Journal of Environmental Policy \& Planning, DOI: 10.1080/1523908X.2021.2022467

\title{
Tackling material dependency in sustainability transition: rationales and insights from the agriculture sector
}

\author{
Luigi Pellizzoni (Università di Pisa) and Laura Centemeri (CNRS, CEMS)
}

\begin{abstract}
Human material dependency is hardly questioned as such. However, there are different understandings of humans' connection with their biophysical milieu. In this paper we discuss four basic accounts, which differ according to whether dependency and agency are assumed to be strong or weak. Though these accounts, which we label as Cartesian, Kantian, Spinozian and Adornian, are ideal-typical, we argue they express a cognitive path dependency that can be detected in the diverse ways the transition to sustainability is pursued. To show the heuristic value of the typology we focus on agriculture, as a field of major relevance in this regard. The first three rationales, respectively underpinning industrial agriculture, ecosystem services and earth restoration programs, see material dependency as a problem to which the reply is mastering the world, though such mastery is understood differently. The fourth one, which underpins peasant agroecology, sees dependency as a constitutive - that is, unavoidable and formative - limitation, pointing to a caring, friendly attitude. We argue this outlook is crucial to a sustainability transition, and give a clue to the governance approach that may help support it.
\end{abstract}

Keywords: ecosystem services, earth restoration, peasant agroecology, vitalism, Adorno and non-identity

\section{Introduction}

That material dependencies play a major role in human life is hardly contested. Human beings have to organise themselves socially and in an environment to survive. In question, rather, is how dependency is to be understood. The issue gets a sense of urgency from the ecological crisis. Environmental threats and turbulences indicate that biophysical materiality can hardly be regarded anymore as a mere support to human activities, unproblematically available for any purpose. Likewise, sustainability transition appears more than just a question of will. Materiality stands in the way of policy decisions in a variety of manners: from growing energy costs of resource extraction to declining marginal returns on organizational and technical investment in innovation (Tainter 2006; Bonaiuti 2018).

In recent years there has been an upsurge in attention towards socio-material entanglements, as part of a broader detachment from traditional realism vs. constructivism diatribes to the benefit of more nuanced accounts of how human agency is affected by material affordances, whether natural, artefactual or hybrid (Coole and Frost 2010; Van Assche et al. 2022). The micro-analytical level typical of STS and the sociology of practices (e.g. Shove 2012) has been complemented by attempts to account for multi-layered patterns in sustainability transition (Geels and Schot 2007). The role therein of infrastructures (energy, transport etc.) has come under extensive scrutiny (e.g. Bulkeley et al. 2013; Birch 2016). To a significantly lesser extent has that of the intertwining of materiality and sense-making in governance approaches (Duineveld et al. 2017; van Assche et al. 2017).

This paper aims to contribute to this strand of inquiry. Our approach is to a certain degree ideal-typical but it is best described as adopting a pragmatist-institutionalist methodological standpoint (see Diaz-Bone 2011). We identify four accounts of material dependency which can be found in as many different ways of theorising human action that have emerged in modern thought and are still at work in defining viable solutions for the transition to sustainability. These accounts define different figurations of action that have 
To cite this article:

Luigi Pellizzoni \& Laura Centemeri (2022) Tackling material dependency in sustainability transition: rationales and insights from the agriculture sector, Journal of Environmental Policy \& Planning, DOI: 10.1080/1523908X.2021.2022467

historically influenced policies and practices in Western societies. What interests us is to point out the rationale of different takes on material dependencies since they inform different logics of coordination and evaluation, resulting in different forms of experience of material dependency, that can be considered as common knowledge.

We focus on agriculture and food production as a crucial sector for the transition to sustainability. As widely acknowledged, the industrialization of agriculture has led to consequences of ecological degradation, from soil erosion to deforestation, to water pollution.

The ideal-types we identify are replies to material dependency as a problem - rather than just a fact, as typical of pre- or non-modern societies - in the framework of the modern thrust to emancipation from need, in turn seen as a struggle to deal with uncertainty (Wagner 2001). The mastery of the world has been the largely predominant answer to the problem. This appears in many ways: from the intimate connection between scientific knowledge and technical domination of the world (Blumenberg 2009), to how modern governmental activities regard the management of the population and its biophysical milieu as their main problem and task (Foucault 2007). We shall see, however, that the idea of world mastery has taken different declensions, seeking either to contain or to let loose uncertainty. We shall see as well that another outlook on uncertainty and material dependency has arisen, pointing to a caring, friendly attitude, where dependency as limitation is acknowledged to be constitutive, i.e. both unavoidable and formative.

Our procedure was abductive. Starting point was the observation of different co-existing approaches to material dependency in agriculture, whose divergences we endeavoured to draw to a few basic variables, going back to the empirical field to see whether in this way more light could be shed on their rationales, affinities and divergences. For economy of space, however, in the following we start with presenting the typology of rationales of material dependency. We then elaborate on these, as found at work in different approaches to agriculture. Main purpose of this paper is to present the typology and offer evidence of its analytical usefulness. However, in the conclusion we argue that the fourth outlook, as found in peasant agroecology, is crucial to a sustainability transition, and give a clue to the governance approach that may help support it.

\section{Conceptualizing material dependency}

To reflect on material dependency the relevant variable is not only dependency itself but also agency. Idealtypically, one can distinguish between strong and weak forms of dependency, according to the degrees of freedom with which the human agent is (supposed to be) equipped vis-à-vis the biophysical milieu - the greater the freedom, the weaker the dependency.

However, it would be a mistake to assume that strong dependency entails weak agency and vice versa. In fact, strong agency means strong possibility to affect the environment, whatever the degrees of freedom the latter allows. On the contrary, weak agency entails weak capacity to affect it, even in case the human agent has ample room for manoeuver. So, what counts is the combination of the two variables: the strength of the link between agent and environment and the leverage the former has on the latter. Table 1 proposes a label for each occurrence, which we are going to explain.

Table 1 - A typology of material dependency

\begin{tabular}{|c|c|c|}
\hline agency & Strong & weak \\
\hline dependency & Spinozian dependency & Adornian dependency \\
\hline strong & Cartesian dependency & Kantian dependency \\
\hline
\end{tabular}


To cite this article:

Luigi Pellizzoni \& Laura Centemeri (2022) Tackling material dependency in sustainability transition: rationales and insights from the agriculture sector, Journal of Environmental Policy \& Planning, DOI: 10.1080/1523908X.2021.2022467

Let's start with Cartesian and Kantian dependency. By these expressions we mean accounts of the relationship between humans and materiality that assume a separation between human mind's internal states and the external world; that 'our bodies are part of the physical world, yet in certain respects we also stand outside it, able to observe and study it, and to characterize it as physical' (Habgood 2002: 5). The difference lies in how access to the external world is conceived. For naïve realist accounts, which correspond to a sort of baseline Cartesian realism, senses provide a direct connection with it.

Representational accounts - that is, accounts assigning a crucial role to mental states - imply a more elaborate relation. For both Descartes and Kant the world must have a stable structure, otherwise any valid knowledge would be impossible. Validity is gauged according to operational success: the capacity to reach one's goals. Both Descartes and Kant, therefore, believe in a correspondence between mental and material states. Yet Kant holds we have access only to phenomenal reality - rather than actual reality, as Descartes claims - i.e. reality as filtered by our perceptual capacities and structured according to our a priori categories of cognition. It is not mind that conforms to objects, but the other way round.

The Cartesian actor is paradigmatic of the idea of strong agency over, and weak dependency on, materiality. The Kantian actor is instead paradigmatic of the idea of weak agency over materiality (there is no way to access what actually happens there), which however does not entail strong dependency, as long as the handling of phenomena is efficient. Whether technology applies to actual or phenomenal reality is irrelevant to its effectiveness, nor does this affect the validity of scientific knowledge, as long as its confirmation lies in predictive success. Kantianism has actually intensified in science since the early twentieth century, with growing acknowledgment that evidence is affected by observation. The same applies to economics: for mainstream (neoclassic) approaches what counts for an effective handling of resources is not their material character but its monetary representation, with which 'preferences' residing in the agent's mind are confronted. Both ways - by direct or indirect control - material dependency is therefore kept at bay. Indeed, human history can be narrated as a history of growing control of, hence independency from, materiality, ensured by relentless improvement in reasoning and conceptualization, with their performative translations into the (real or phenomenal) world.

However, other ontologies have arisen in modern thinking, holding there is no separation between mental and physical states, mind and body, conceptualization and reality. Non-dualist accounts have taken two main directions. Largely predominant is a vitalist one. From the assumption of the untenability of distinctions such as subject and object, active and passive (or merely reactive), living and non-living, the route taken by a host of thinkers is to extend vitality to the whole reality, as with Spinoza's influential notion of 'conatus' (a generalized will to live, continue, expand). Vitalism has witnessed a powerful boost in recent times (Greco 2005), from Spinozian post-structuralism (e.g. Deleuze) and Marxism (e.g. Negri) to revamped interest in philosophies of nature such as Whitehead's (Stengers 2008). Burgeoning 'new materialisms' in social theory (Coole and Frost 2010) subscribe to an ontology of flows and endless becoming. Matter is depicted as provided with inventive capacities, generative powers, forcefulness; distinctions such as language/matter, organic/inorganic or nature/technology are declared obsolete; and vitality and agency are deemed equally distributed among humans and nonhumans.

In short, vitalisms provide materiality with a strong agency, without detracting from human agential capacities. There is, however, another route a non-dualist ontology can take, eminently represented by Adorno. For him it is true that subject and object, thought and things, are enmeshed from the outset. Both humans and nonhumans are bodily, physical. And thought has non-conceptual, sensuous, material constituents. Yet 'the subject is also an object, which means that the subject cannot be thought independently of the object, whereas the object can be thought independently of the subject' (Adorno 2004: 183). Hence, things bear primacy over thought. Conceptualization has both a logical element, 'through which thought identifies different particulars (individuals or properties of individuals) as belonging to the same 'concept", finding similarities and equivalences crucial to acting in the world, and a material element, 'object-depending or object-involved', which leads to an 'intransitive understanding' (Bernstein 
To cite this article:

Luigi Pellizzoni \& Laura Centemeri (2022) Tackling material dependency in sustainability transition: rationales and insights from the agriculture sector, Journal of Environmental Policy \& Planning, DOI: 10.1080/1523908X.2021.2022467

2001: 33-34; cf. Adorno 2004: esp. 11 ff., 151 ff.). Acknowledging such understanding means acknowledging the uniqueness of each encounter with materiality; the inherent incompleteness of any conceptualization. 'Identity-thinking', the modern perverted mimetic relationship with the world, the attempt of reason to dominate it by way of assimilation to its own categories, builds on the denial of the primacy of things, focusing on the logical element of conceptualization to the detriment of intransitive understanding. Such understanding has to be recovered, basing action on the acknowledgment of matter's 'non-identity' with thought. This is not the usual disclaimer about the ever-perfectible state of scientific knowledge, which in fact permits and encourages decisions taken as if such knowledge was complete, or at least sufficient for handling the world according to purposes, ruling out unfitting reminders. It is instead the recognition of incompleteness as a constitutive condition to which action should conform, pointing to an empathic mimesis: not a drawing of the object to the subject but a going of the subject towards the object, with an attitude of humbleness stemming from the acknowledgement of the impossibility of doing full justice to it; a demand of friendship rather than an attempt at lordship.

In short, in Adorno's account of the relationship between humans and the rest of the world, dependency is strong, and agency weak. Of the four outlooks, this is the only one that puts human agency in a lesser position vis-à-vis the world, making knowledge inseparable from an affective tonality which goes beyond the scientist's curiosity about and intimacy with the object of inquiry to include a caring attitude.

\section{Material dependency in agriculture}

The task is now to show the heuristic value of this typology of material dependency and human agency for the debates over which type of agriculture should be supported to address the ecological crisis while providing for world population's needs. Our typology (see table 1 ) helps clarify the epistemological matrices underlying relevant approaches to agriculture debated today in relation to the ecological transition (see table 2). Diversity of approaches reflects on the persistence of a variety of 'styles of farming', intended as 'a concrete form of praxis, a particular unity of thinking and doing, of theory and practice' (Van der Ploeg 1993: 241).

Table 2 - A typology of approaches to material dependency in agriculture

\begin{tabular}{|c|c|c|}
\hline dependency & Strong & Weak \\
\hline strong & Earth restoration & Peasant agroecology \\
\hline weak & Industrial agriculture & Farming for ecosystems services \\
\hline
\end{tabular}

Such diversification is usually related to two outlooks on the relationship with nature: on one side the idea that agricultural production depends on 'exogenous inputs', its sustainability consequently relying on technological progress; on the other, that it depends on a set of ecosystem services, sustainability thus depending on how food systems are designed, as territorially embedded or dependent on global food chains (Plumecocq et al. 2018). We complexify this account by considering different kinds of 'agricultural agency' and 'agricultural materiality' at play in the observable variety of forms of agriculture.

\section{Industrial agriculture and the 'Cartesian theatre'}

Industrial, or conventional, agriculture epitomizes the strong agency and weak dependency we have defined as Cartesianism. The industrial turn in agriculture - so-called 'Green Revolution' - takes hold after World War II. It builds on new variety selection according to adaptability to highly heterogeneous contexts and performance. It entails extensive irrigation; chemical fertilizers and pest control, resistance to diseases, high mechanization, adaptability to industrial processes, and so on. Features further emphasised by the 
To cite this article:

Luigi Pellizzoni \& Laura Centemeri (2022) Tackling material dependency in sustainability transition: rationales and insights from the agriculture sector, Journal of Environmental Policy \& Planning, DOI: 10.1080/1523908X.2021.2022467

application of gene technologies. This model of agriculture is based on a notion of soil as an inert medium whose specific characteristics count for little. Varieties are chosen in the lab, mainly on the basis of productivity, and introduced into fields, which are transformed (pesticides, fertilizers, mechanization...) so as to offer optimal, i.e. standardized, soil conditions. Agriculture, thus, consists in the application of rules of general validity that transpose proven scientific knowledge from lab to field. In this sense, industrialization and academicization of agriculture go hand in hand.

The Green Revolution has transformed the peasant condition worldwide (Van der Ploeg 2008). Farmers are invested by instrumental rationality, becoming at once implementers of techniques elaborated elsewhere, to which they have to be trained, and entrepreneurs driven by the pursuit of profit. Agriculture becomes part of a 'Cartesian theatre' (Thompson 2010). Most relevant knowledge is deemed coming from 'fundamental laws of natural science as specified in biology, chemistry, biochemistry, physics, economics, etc.', so that a 'restructuring of agriculture' can only 'be derived from these "fundamental" insights and models' (Van der Ploeg 1993: 241). Decontextualized rationality trumps practical and contextual knowledge. As said, for such rationality to operate effectively, materiality has to be heavily transformed, (allegedly) recreating in the field the controlled conditions of the lab, reducing uncertainty and increasing productivity. In this way both materiality and mentality are transformed. Transformation is at once technical, cognitive and cultural.

Since Rachel Carson's Silent Spring, consensus has broadened over the role of industrial agriculture in the ecological crisis, from biodiversity loss to pollution and resource depletion (particularly water). A critique of working conditions, concentration of land ownership and, more recently, seed patenting has added, connecting ecological and social exploitation. Yet, supporters of gene technologies or digital, 'precision', agriculture claim that, if the Cartesian approach is at the origin of the problem, it can also be the solution, reducing the overall quantity of inputs and (partly) replacing chemistry with genetic engineering. Once more, technical advancement is finalized to addressing soil as a passively reactive layer, in which inputs are injected to get growing process control. Uncertainty is tackled by levelling context-specificities, either ignoring or translating them into finely adjusted standards. The field makes eventually no difference from the factory, as a space organized so to ensure 'scalable' (Tsing 2012) and entirely controllable codified production processes. In this framework, even precision agriculture, often presented as decisive for an ecofriendly turn of industrial agriculture, is less of a game changer than a refinement of means to the same purpose, pretty much as happened with the rise of the 'lean' economy in reply to the inefficiencies of the Fordist factory. The same can be said for those forms of organic farming that while using biomimetic tools and strategies to avoid the use of chemicals, do not challenge the industrial logics of organisation of production. Recurring to 'biomimicry', thus valorising - in a Spinozian fashion - the agency of nature, does not per se imply a different systemic approach to uncertainty. The creation of 'organic' labels related to certification systems that require the standardization of productive procedure is today more often than not functional to confirm the Cartesian approach to agriculture. The point, in other words, is not - according to a classic 'ecological modernization' vs. 'treadmill of production' (Mol and Sonnenfeld 2000; Schnaiberg and Gould 1994) framework of reasoning - whether capitalist relations act as a trigger or an obstacle to developing the potential of organic agriculture (Obach 2007), but whether changing the means of production can ever provide resolutive answers if the logic and goals of their application remains unchanged.

\section{Earth restoration: biomimicry and the 'true' wealth of healthy ecosystems}

It is from an opposite understanding of soil, as 'living entity that affects and is affected by its environment through numerous biogeochemical processes' (Goreau et al. 2015: XV) that approaches have emerged which aim to offer a solution to global issues of both food security and climate change through small and large-scale programmes of ecological restoration of farmland (Wade et al. 2008). 
To cite this article:

Luigi Pellizzoni \& Laura Centemeri (2022) Tackling material dependency in sustainability transition: rationales and insights from the agriculture sector, Journal of Environmental Policy \& Planning, DOI: 10.1080/1523908X.2021.2022467

Ecosystems restoration (ER) programs have been promoted since the 1990s in terms of 'Geotherapy' (Grantham 1992) and 'Earth restoration' (Gritzner et al. 2011). This terminology echoes notions such as 'geopower' (Povinelli 2016) and 'intrusion of Gaia' (Latour 2017), that have been gaining momentum, signalling the growing political import of planetary dynamics. A significant feature can be traced in this literature: the acknowledgment of matter's agency does not sound as an invitation to caution and humbleness, but as an incitement to ride 'some of the potential of forces that will always exceed our understanding and utilization' (Clark 2017: 228). A similar attitude can be found in the case for ER. The focus is on human capacity of restarting virtuous processes of co-evolution with the Earth, directing and sustaining planetary forces to engender ecological diversity and abundance, reversing the destructive effects of current socio-ecological organization. Humans depend on Gaia, but Gaia can be 'healed'. Rather than relying on the Cartesian techniques at the origin of the problem, one is to take a Spinozian route, fully embracing dependency, setting nature dynamics as the reference for human technical creativity. The idea, in other words, is to support the 'inherent' regenerative potential of healthy systems. The soil is seen as a biotic community which includes human beings. Humans are a force of nature that can act for nature's sake thanks to their inventiveness in mimicking natural processes, the latter providing inspiration for responding to their own needs. Thus, biomimicry is the keyword, pointing to widespread, bottom-up soil restoration initiatives, often building on traditional forms of agriculture and involving local knowledge and practice (Gritzner et al. 2011: 1348), hence based on low-tech solutions, yet implying high-level scientific understanding and managing capacities of programs which, even if implemented at small-scale, require large-scale coordination and results. A variety of movements of soil regenerators and ecosystems restorers has arisen that support 'ongoing creative experimentation' (Clark and Yusoff 2017: 18), preparedness and resilience, flexibility, trial and error. The aim is to embrace a condition of precariousness whose positivity is exalted, in its being a mirror of the way nature organizes itself.

The importance of soil restoration has been stressed as a way to contribute to carbon sequestration since agricultural soils are considered as carbon sinks. There are calls for a 'global-scale soil climate mitigation strategy' (Amelung et al. 2020) that encourages large-scale environmental rehabilitation projects. An example is the environmental rehabilitation of the Loess Plateau (LP) in China (Liu and Hiller 2015), once barren and exposed to erosion and now largely covered with vegetation.

The ecological sustainability and the social implications of this operation are however controversial (Wu et al. 2019). This applies to some extent to its very foundations and relations with other approaches. Since 1999, the LP has been a pilot region for China's 'Grain to Green Program' (GTGP), the world's largest Payment for Ecosystem Services program. However, the ER approach differs from that of ecosystem services (see below). For the supporters of ecosystem restoration ecosystem services are derivatives of functional ecosystems, and valuing the former higher than the latter creates 'a perverse incentive to degrade the ecosystem', whereas the key is 'to value the ecosystems more highly than the things that are extracted or manufactured' (Liu and Hiller 2015: 370, 377). Value, therefore, is related to the material reality of dependency: without functioning ecosystems, there can be no life on earth. There is a 'real' and a 'false' wealth and socioecological transformation rests on a 'consciousness shift and behavioural change' (Liu and Hiller 2015: 376).

\section{Farming for ecosystem services: agriculture as managing externalities}

The economy of ecosystem services (ES) exemplifies a Kantian account of material dependency. In the Kantian world, one never encounters things: only monetary aliases. Degradation is read in terms of market failures in accounting for scarcity through pricing. In reply, attempts have been made at 'framing overflows' (Callon 1998), that is accounting for negative externalities, including in monetary calculation elements of (phenomenal) reality as yet disregarded. 
To cite this article:

Luigi Pellizzoni \& Laura Centemeri (2022) Tackling material dependency in sustainability transition: rationales and insights from the agriculture sector, Journal of Environmental Policy \& Planning, DOI: 10.1080/1523908X.2021.2022467

The ES logic is not originally Kantian. Its legacy is Spinozian. At its roots lies eighteenth-century Physiocrats' account of wealth production. Physiocrats held that in human work on matter part of its wealth is inevitably wasted. They addressed agricultural practices and their yields. Late twentieth-century ecological economists, instead, focus on the metabolic processes occurring in the biosphere, which social metabolism intercepts with its tap and sink activities. This introduces a first Kantian drift. While thinking in terms of yields implies keeping track of both quantitative and qualitative distinctions, thinking in terms of chemical exchanges and energy flows makes the latter virtually disappear. A second, and crucial, Kantian drift comes with the notion of 'natural capital', followed by that of ES, appeared in the early 1980s (Ehrlich and Ehrlich 1981). The original meaning of both was metaphorical. The aim was to gain attention in mainstream economic and policy circles by using a customary language (Gómez-Baggethun et al. 2010). In fact, both notions have been enthusiastically adopted, also by NGOs (Hrabanski 2015), with a flourishing of monetary valuation techniques and influential endorsements from the UN (Millennium Ecosystem Assessment 2005) and the European Commission (2013).

ES are defined as the benefits biophysical systems give to humans, from resource provision to regulative and supporting functions like carbon sequestration, waste decomposition, soil formation, crop pollination, to cultural and recreational ones. The economy of ES builds on the identification and measurement of instances of these functions. On this view, agriculture is a managed ecosystem, provider and receiver of ES that more often than not lack proper markets. Agriculture supplies all three major categories of ES, provisioning, regulating and cultural, which often overlap. A cultivated field can be at once soil, landscape, culturally and historically marked territory, place endowed with personal and collective memories. This heterogeneity, or ontological multiplicity (Mol 1999), is drawn to commensurable functions, central importance being given to enhancing the 'scientific understanding of the linkage between changes in agricultural management and changes in resulting ES flows', through 'cost-effective monitoring via sensing technologies and other indicators' (Swinton et al. 2007: 249-50, 251), in order to effectively steer the incentive system, seen as investments that society makes out of a rational decision and that must pay off. In this framework, the farmer is seen as a self-interested actor aimed at maximising utility. Monetary valuation is thus necessary to 'induce agricultural land managers to provide (or maintain) ES at levels that are desirable to society' (Swinton et al. 2007: 248).

Incentives are either business-to-business or mediated by government interventions. They take two main forms: markets or payments. Markets for ES (MES) are created when functions are deemed to be incorporated in things located in different places, so that one can for example 'offset' damage to some wetland or forest with wetland or forest created or restored elsewhere. Payments for ES (PES) are instead transactions by which a process such as carbon sequestration in biomass or freshwater flows is disentangled from the network of functionings and relations of which it is part and its provision is secured to a buyer. In the case of MES we have what Castree (2003) calls a spatial and a functional abstraction; in the case of PES only a functional one. Abstraction means neglecting, 'cutting away', the variety of (known and unknown) functionings a given portion of biophysical materiality enacts, or the values attributed by different users to a certain functioning or bundle of functionings (Robertson 2000; Norgaard 2010). This entails constructing taxonomies, defining functions, breaking down and recomposing processes, assigning them values and packaging such values into financial instruments (Robertson 2012). In turn, this means establishing and accepting scientific and economic abstractions and the translatability of the respective quantifications.

Thus, though the ES perspective takes into account ecological interdependencies (Swinton et al. 2007), these are drawn to categories (function, service) that allow for their rational management, while ongoing improvement of scientific knowledge and monitoring helps refine detection of (dis)services. In a true Kantian fashion, human agency progressively strengthens in a world of pure representations. Overflows can be ever-more effectively framed. In this case there is no 'real wealth' of healthy ecosystems to be 
To cite this article:

Luigi Pellizzoni \& Laura Centemeri (2022) Tackling material dependency in sustainability transition: rationales and insights from the agriculture sector, Journal of Environmental Policy \& Planning, DOI: 10.1080/1523908X.2021.2022467

contrasted with the 'false wealth' of money. Money authorizes the commensuration of different reasons to value and the calculation of costs and benefits.

A different take on ES comes from a minority of ecological economists who contest assumptions of strong or weak commensurability of values (i.e. their measurability on a cardinal or ordinal scale), subscribing to the idea of weak comparability and the resulting need of multicriteria evaluation methods (Martinez-Alier et al. 1998). On this view, 'the value assigned to different functions where no markets exist or where values go beyond markets (e.g. conservation) is always a matter of interpretation' (Chen et al. 2020: 5). The multifunctionality of agriculture implies that judgment about what counts as value is preliminary to any assessment. This resonates with the Economics of Conventions school's claim that judgments of worth are based on incommensurable metrics, each grounded on own criteria, market competition being just one (Boltanski and Thévenot 2006). Accordingly, when observing an organized activity (in our case farming), one can notice different ways agents put material dependency into 'forms' (Thévenot 1984), which allows for different types of agency to emerge. This approach brings to the fore a kind of uncertainty that touches not knowledge about reality but the situation as experienced. Acting requires interpreting what does and doesn't count as relevant, and this depends on the experience lived and pursued. For example, a 'wetland' can be regarded as a resource but also as heritage, biodiversity, wilderness, dwelled place, and else, according to what agents value, for which purpose.

For some ecological economists this is an epistemic question; a question of outlook on reality, of the language used to account for it. This is suggested by Martinez-Alier's (2002) notion of 'languages of valuation'. Alternatively, one can claim the question is ontological: of reality as enacted (Mol 1999), that is, brought to exist and experienced through 'investing in forms' (Thévenot 1984). In this latter account, there is a multiplicity of ways of actualizing material dependency, to which cognitive categories and value discourses are attached. The Adornian theme of incompleteness, of an irreducible uncertainty about material dependency, is evoked here. Awareness of that, complemented with a peculiar understanding of the way it matters, is what characterizes a fourth type of agriculture.

\section{Peasant agroecology: shaping and taking care of socioecological solidarities}

Peasant agroecology is the term we use to refer to a variety of individual and collective actors who practice and promote peasant agriculture as an alternative to conventional agriculture, also as a form of resistance against the industrialization and financialization of the sector. By peasant agriculture we mean small scale farming committed to circular economy principles (less exogenous inputs and waste), multifunctionality, healthy food, soil regeneration, biodiversity maintenance, support of local economies, solidarity and mutualism. Peasant agroecology is based on the amelioration of traditional farming techniques through infield experimentation, relying on different knowledges (including scientific, e.g. about soil composition) and contributing to the maintenance of rural landscapes and cultures.

There is no theoretical account of peasant agroecology (Van der Ploeg 2008), which helps explain its neglect in mainstream debates over the ecological transition of agriculture. Transnational networks have however emerged, most notably Via Campesina (born in 1993), through which peasants try to count in global governance.

For Van der Ploeg, peasant farming 'relate[s] to nature in ways that sharply differ from the relations entailed in other modes of farming' (2008: 21), shaping production and moulding and developing social and natural resources in distinctive ways. Peasants struggle for autonomy in organizing practices in forms specific to context and the (human and non-human) beings involved, so as to guarantee their reproduction and maintenance over time. Theirs is therefore a 'bounded' autonomy, based on awareness of the socioecological interdependencies on which subsistence rests, hence on the inseparability of production, reproduction and consumption. As Elinor Ostrom's research on local commons has documented since the 1990s, socio-material context-specificity does not mean lack of shareable knowledge and insight. A 
To cite this article:

Luigi Pellizzoni \& Laura Centemeri (2022) Tackling material dependency in sustainability transition: rationales and insights from the agriculture sector, Journal of Environmental Policy \& Planning, DOI: 10.1080/1523908X.2021.2022467

significant example comes from 'seeds movements', which in countries such as Spain, France and Italy reclaim and share seeds (Demeulenaere and Piersante 2020). Furthermore, as Van der Ploeg (2008) notes, peasant farming is not static or backward-looking. Rather, improvement, or progress, is thought differently, holding together human subsistence and context-dependent ecosystem maintenance. Significant in this respect is collaboration between science and peasant practice. One example is 'participatory plant breeding': a 'decentralized, transdisciplinary and multi-actor process of plants selection, commonly based on collaborations between farmers and breeders (geneticists and agronomists)' (Demeulenaere and Piersante 2020: 3), resulting in 'heterogeneous' genetic materials, that is, varieties of a species allowing for context-specific adaptation. It is crucial here to gauge the difference with conventional scientific approaches. Experiments are conducted in the fields, managed by peasants who have equal rights with scientists in decisions, for example about choice of varieties to include in the experiment. Methodologies adjust to different contexts rather than the other way round. Plant selection becomes in this way an exercise in 'technologies of humility' (Jasanoff 2003), often lacking institutional support precisely for its 'modesty', the acknowledgment of limits to standardization.

We are at odds here with classic, Cartesian understandings of experimentation, based on isolation and generalization of experimental conditions according to equally distinct, isolated and generalizable parameters of success. But we are distant as well from Spinozian unconditional trust in vitalism and the virtue of biomimicry. The idea of earth restoration is present in peasant agroecology, especially among global North's 'new peasants' (Van der Ploeg 2008). And agroecological practices can be included in ER programs. The difference, however, lies in the way uncertainty is put into play, and hence mimesis is understood - in the case of peasant agroecology, in an Adornian, empathic, way. The same holds for biodynamic farming. Since the early twentieth century some peasant farmers, first in Europe and then in North America, have been adopting techniques inspired to Rudolf Steiner's approach to agriculture, based on a vitalist understanding of the natural world and integrated into the larger spiritual philosophy of anthroposophy. This worldview, however, is not necessarily shared by farmers adopting biodynamic methods, which are often considered in terms of case-by-case effectiveness. Moreover, the creation of standardized certification for biodynamic farming has created a profitable niche market (see Bivar 2018) .

In fact, the peasant way of farming is not based on a theory of agricultural production, but on experience, direct and conveyed by local knowledge, and on observation of ecological processes in their concrete becoming, sensitive to discontinuities and anomalies. It is not a drawing of things to one's will, either by harnessing reality or mimicking its vital dynamics, but a going towards things where logical conceptualization is complemented by an intransitive understanding, that is a regard for vital processes as they are experienced here and now. In this way radical uncertainty is acknowledged and enacted not so much as an overarching condition on the crest of which humans can sit and fly, but as something revealing itself only in specific manifestations, that act as triggers of and limitations for action. Against the generalizability of Cartesian experiments and Kantian measurements or the undifferentiated vitality at the centre of Spinozian ones, it is the embeddedness of experimentation what is relevant to peasant agroecology. It is neither a matter of forcing ecological dynamics to conform to externally imposed patterns, whether actual or figurative, nor of letting or inciting such dynamics do their job (for us), but of walking together, reciprocally affecting and effecting along the way, interdependence uniting and singularizing at once.

Following Mol (2008), one can say that agroecological peasants give centrality to a 'logic of care' as distinct from the 'logic of choice'; a logic of valuation grounded on the experience of relationships, contexts and beings as weakly comparable, i.e. at once bearing affinities with and irreducible to one another, hence impervious to an infinite expansion of monetary equivalence and an account of the market as a neutral tool of coordination. Moreover, the logic of care implies both activity and receptivity (caution, sensitivity, patience...) pointing to a humble agency, opposite to the dominative one at work in biotech and precision 
To cite this article:

Luigi Pellizzoni \& Laura Centemeri (2022) Tackling material dependency in sustainability transition: rationales and insights from the agriculture sector, Journal of Environmental Policy \& Planning, DOI: 10.1080/1523908X.2021.2022467

approaches and lurking behind accounts of biomimicry as a technique of innovation (Benyus 1997), pursued by Earth healers and restorer heroes.

More decidedly than in ecosystem restoration, peasant agroecology brings about a type of agriculture in which material dependency is recognized as a commonality of destiny, the source of socioecological solidarities and human-nonhuman obligations, resulting in context-specific rules and institutions. This corresponds to a radical critique of both market capitalism and forms of state dirigisme, because rooted in the acknowledgement of the irreducibility of agroecological practice to norms of general validity and of the inseparability of production, reproduction and consumption - of what (food), whereby (biophysical materiality) and how (eating). The articulation of these 'agrarian ideals' (Thompson 2010) to social goals of freedom, equality, and emancipation is today the focus of intense social experimentation within a variety of socioecological movements (Centemeri 2018).

\section{Conclusion: for a politics of material dependency}

To recap, different accounts of human agency and material dependency lead to different outlooks on the ecological transition, according to which different ways of practicing agriculture can be investigated. When applying our typology it appears that, in spite of being unanimously considered at the origin of the crisis, Cartesian approaches still hold strong. They point to a technological leap forward to increase control over agricultural production by way of increased automatization. The case for ecosystems restoration builds instead on the idea of biomimicry, a Spinozian gesture of elicitation of and insertion in the vital dynamics of Gaia. The ecosystem services approach seeks to improve, in a Kantian fashion, appraisals of the utility that biophysical materiality gives to humans. Peasant agroecology highlights an Adornian outlook on matter's limited pliability to human designs, making a case for acknowledging the contextual embeddedness of socio-material interactions and the fictitiousness of a separation between production, reproduction and consumption, or between practice-based and scientific knowledge.

Our perspective therefore helps to go beyond the opposition between an 'industrial vision' and an 'agrarian vision' of agriculture, pointing to a more complex scenario, while confirming the relevance of theoretical insights into material dependencies for thinking about agricultural policies, and the relevance of agricultural policies to think about sustainability issues.

Discussion brought to light two issues intimately linked to how agency and material dependency are conceived. First is the question of value - how accounts of agency and material dependency affect the definition of worthiness. In the Cartesian framework value is a substance that can be mastered; in the Kantian one value is related to utility and human preferences; in the Spinozian it is connected with living dynamics; in the Adornian it does not exist in the abstract but in relation to a materially embedded experience. Second issue is uncertainty. Both the Cartesian and the Kantian rationale aim to reduce uncertainty, either in tackling matter or in identifying and composing individual utilities, to improve the mastery of the world. The Spinozian rationale celebrates uncertainty as the inexhaustible force of materiality, to which humans can learn to attune. The Adornian rationale sees uncertainty as an existential condition the acknowledgment of which entails addressing materiality unassumingly and caringly, as a question of togetherness, of reciprocal adjustment rather than imposing one's own purposes.

Significantly, from a policy perspective, concrete initiatives of agricultural transformation do not highlight only the presence of contrasting rationales, but also their contacts. We have seen, for example, how ER intertwines with ES programs and agroecological practices. Additionally one can observe experimentations in bioregional planning that seek to combine the ES approach with peasant agroecology - a possibility theoretically suggested by accounts of weak comparability of ES values. Key conceptual move here is replacing 'nature' with 'territory' as a backdrop for conceiving ES, which in this way result entangled with human settlements and the host of interventions whereby communities take care over time of their homeland; hence typically multifunctional, integrated and localized. The abstract notion of function is 
To cite this article:

Luigi Pellizzoni \& Laura Centemeri (2022) Tackling material dependency in sustainability transition: rationales and insights from the agriculture sector, Journal of Environmental Policy \& Planning, DOI: 10.1080/1523908X.2021.2022467

replaced with the contextual one of 'rules of reproducibility' of a territorial patrimony, as a social construction built up in a lengthy time by an ensemble of interrelated elements, which include settlements, agrarian practices, high biodiversity areas, contextual knowledges and memories (Poli et al. 2020). Kantian plays of equivalences are replaced by weak comparisons of local interlinkages and situational peculiarities to construct tailor-made management solutions, as such not generalizable but working as model cases.

As said in the beginning, our purpose was to present the typology and give evidence of its analytical usefulness. However, it should be evident that we believe peasant agroecology (and more generally the Adornian outlook) is crucial to a sustainability transition. Yet, it is also at odds with the hypertrophic, everexpansive understanding of human agency that the other outlooks imply and support, each in its own way. Of course, it is impossible to properly demonstrate that Cartesian technological intensification or Kantian internalization of externalities cannot be resolutive of the ecological crisis. Both are intensively applied, with no appreciable overall effect on sustainability. Yet, this can always be read as a a call to insist with their application. However, growing interest in ecological restoration and peasant agroecology shows that the stronghold of uncertainty reduction is under attack. Both Spinozian and Adornian outlooks consider uncertainty (which amounts to material dependency) as a resource for, rather than an obstacle to, action. Indeed, public policies aimed at a radical reorientation of agriculture (and of course other sectors) should take the work of things out of the lab or of the ledger, undetected and to some extent undetectable, not as a problem to fix but an existential condition to acknowledge; not a hindrance to sustainability but a guidance to action. The need to acknowledge and address material dependency in these terms is gaining evidence not only in agriculture but in a variety of fields (Funtowicz and Ravetz 1993). To challenge and induce a shift in the dominant order, however, adequate support should come from both critical and 'prefigurative' social forces (Pellizzoni 2021). Yet, these presently appear fragmented and still in search of a shared sociotechnical imaginary. How to address this problem goes beyond the scope of this paper.

\section{References}

Adorno, T.W. (2004). Negative Dialectics. London: Routledge.

Amelung, W., Bossio, D., de Vries, W. et al. (2020). Towards a global-scale soil climate mitigation strategy. Nature Communications, 11, 5427. https://doi.org/10.1038/s41467-020-18887-7

Benyus, J. M. (1997). Biomimicry. New York: Morrow.

Bernstein, J.M. (2001). Adorno: Disenchantment and Ethics. Cambridge: Cambridge University Press.

Birch, K. (2016). Materiality and sustainability transitions: integrating climate change in transport infrastructure in Ontario, Canada. Prometheus, 34(3-4), 191-206.

Bivar, V. (2018). Organic Resistance. Chapel Hill, NC: University of North Carolina Press.

Blumenberg, H. (2009). Geistesgeschichte der Technik. Frankfurt: Suhrkamp.

Boltanski, L. \& Thévenot, L. (2006). On Justification. Princeton, NJ: Princeton University Press.

Bonaiuti, $\mathrm{M},(2018)$, Are we entering the age of involuntary degrowth? Promethean technologies and declining returns of innovation. Journal of Cleaner Production, 197(2), 1800-1809.

Bulkeley, H., Castan Broto, V. \& Maassen, A. (2013), Low-carbon transitions and the reconfiguration of urban infrastructure. Urban Studies, 51(7), 1471-1486.

Callon, M. (1998). An essay on framing and overflowing: economic externalities revisited by sociology, in M. Callon (ed.), The Laws of the Market (pp. 244-269). Oxford: Blackwell.

Castree, N. (2003). Commodifying what nature? Progress in Human Geography, 27(3), 273-297.

Centemeri, L. (2018). Commons and the new environmentalism of everyday life. Alternative value practices and multispecies commoning in the permaculture movement. Rassegna Italiana di Sociologia, 59(2), 289313. 
To cite this article:

Luigi Pellizzoni \& Laura Centemeri (2022) Tackling material dependency in sustainability transition: rationales and insights from the agriculture sector, Journal of Environmental Policy \& Planning, DOI: 10.1080/1523908X.2021.2022467

Chen, W., Van Assche, K. A. M., Hynes, S., Bekkby, T., Christie, H. C., \& Gundersen, H. (2020). Ecosystem accounting's potential to support coastal and marine governance. Marine Policy, 112, 103758. https://doi.org/10.1016/j.marpol.2019.103758

Clark, N. \& Yusoff, K. (2017). GeosocialfFormations and the Anthropocene. Theory, Culture \& Society, 34(23), 3-23.

Clark, N. (2017). Politics of strata. Theory, Culture \& Society, 34(2-3), 211-231.

Coole, D. \& Frost, S. (2010). (Eds.), New Materialisms. Durham, NC: Duke University Press.

Demeulenaere, E., and Piersante, Y. (2020). In or out? Organisational dynamics within European 'peasant seed' movements facing opening-up institutions and policies. Journal of Peasant Studies, 47(4), 767-791. Diaz-Bone, R. (2011). The Methodological standpoint of the 'Économie des conventions'. Historical Social Research/Historische Sozialforschung, 36(4),43-63.

Duineveld, M., Van Assche, K., \& Beunen, R. (2017). Re-conceptualising political landscapes after the material turn: a typology of material events. Landscape Research, 42(4), 375-384.

Ehrlich, P.R. \& Ehrlich, A.H. (1981), Extinction. New York: Random.

European Commission (2013). Mapping and Assessment of Ecosystems and Their Services. Brussels: European Commission.

Foucault, M. (2007). Security, Territory, Population. New York: Picador.

Funtowicz, S. \& Ravetz, J. (1993), Science for the post-normal age. Futures, 25(7), 739-755.

Geels, F. W., \& Schot, J. (2007). Typology of sociotechnical transition pathways. Research policy, 36(3), 399417.

Gómez-Baggethun, E., de Groot, R., Lomas, P.L., Montes, C. (2010). The history of ecosystem services in economic theory and practice: from early notions to markets and payment schemes. Ecological Economics, 69(6), 1209-1218.

Goreau, T. J., Larson, R. W., \& Campe, J. (eds.) (2015). Geotherapy. Boca Raton; London; New York: CRC Pr. Grantham, R. (1992). Geotherapy as evolutionary choice. Global Environmental Change, 2(1), 2-4.

Greco, M. (2005). On the vitality of vitalism. Theory, Culture \& Society, 22(1), 15-27.

Gritzner, J., Milan, G. \& Berry, L. (2011). The Earth Restoration project: An overview, in S. Brunn (ed.) Engineering Earth (pp. 1343-1352), Dordrecht: Springer.

Habgood, J. (2002). The Concept of Nature. London: Darton, Longman \& Todd.

Hrabanski, M. (2015). The biodiversity offsets as market-based instruments in global governance: origins, success and controversies. Ecosystem Services, 15, 143-151.

Jasanoff, S. (2003). Technologies of humility: citizen participation in governing science. Minerva, 41, 223244 (2003).

Latour, B. (2017). Facing Gaia. Cambridge: Polity.

Liu, J. D., \& Hiller, B. T. (2015). A continuing inquiry into ecosystem restoration: examples from China's loess plateau and locations worldwide and their emerging implications, in I. Chabay, M. Frick, \& J. Helgeson (eds.), Land Restoration (pp. 361-379). Amsterdam: Elsevier Inc.

Martinez-Alier, J. (2002). The Environmentalism of the Poor. London: Elgar.

Martinez-Alier, J., O'Neill, J. \& Munda, G. (1998). Weak comparability of values as a foundation for ecological economics. Ecological Economics, 26(3), 277-286.

Mol, A.P.J., \& Sonnenfeld, D., eds. (2000). Ecological Modernization Around the World. London: Cass.

Mol, A. (1999). Ontological politics. A word and some questions, in J. Law \& J. Hassard (eds.), Actor Network Theory and After (pp. 74-89). Oxford: Blackwell. 
To cite this article:

Luigi Pellizzoni \& Laura Centemeri (2022) Tackling material dependency in sustainability transition: rationales and insights from the agriculture sector, Journal of Environmental Policy \& Planning, DOI: 10.1080/1523908X.2021.2022467

Mol, A. (2008). The Logic of Care. London: Routledge.

Norgaard R.B. (2010). Ecosystem services: from eye-opening metaphor to complexity blinder. Ecological Economics, 69(6), 1219-1227.

Obach, B. (2007). Theoretical interpretations of the growth in organic agriculture: agricultural modernization or an organic treadmill? Society \& Natural Resources, 20(3), 229-244.

Pellizzoni, L. (2021). Prefiguration, subtraction and emancipation. Social Movement Studies, 20(3), 364-379.

Plumecocq, G., Debril, T. Duru, M., Magrini, M.B., Sarthou, J. \& Therond, O. (2018). The plurality of values in sustainable agriculture models: diverse lock-in and coevolution patterns. Ecology and Society, 23(1), 21. https://doi.org/10.5751/ES-09881-230121.

Poli, D., Chiti, M. \& Granatiero, G. (2020). L'approccio patrimoniale ai servizi ecosistemici, in D. Poli (ed.), I servizi ecosistemici nella pianificazione bioregionale (pp. 1-34). Firenze: Firenze University Press.

Povinelli, E. (2016). Geontologies. Durham, NC: Duke University Press.

Robertson, M. (2000). No net loss. Antipode, 32(4), 463-493.

Robertson, M. (2012). Measurement and alienation: making a world of ecosystem services. Transactions of the Institute of British Geographers, 37(3), 386-401.

Schnaiberg, A. \& Gould, K. (1994). Environment and Society. New York: St. Martins Press.

Shove, E. (2012). The Dynamics of Social Practice. London: Sage.

Swinton, S. M., Lupi, F., Robertson, G. P., \& Hamilton, S. K. (2007). Ecosystem services and agriculture:

Cultivating agricultural ecosystems for diverse benefits. Ecological Economics, 64(2), 245-252.

Tainter, J.A. (2006). Social complexity and sustainability. Ecological Complexity, 3, 91-103.

Thévenot, L. (1984). Rules and implements: Investment in forms. Social Science Information, 23(1), 1-45.

Thompson, P. B. (2010). The Agrarian Vision. Lexington: The University Press of Kentucky.

Tsing, A. L. (2012). On nonscalability. Common Knowledge, 18(3), 505-24.

Van Assche, K., Beunen, R., Duineveld, M., \& Gruezmacher, M. (2017). Power/knowledge and natural resource management: Foucaultian foundations in the analysis of adaptive governance. Journal of environmental policy \& planning, 19(3), 308-322.

Van Assche, K., Duineveld, M., Gruezmacher, M., Beunen, R., \& Valentinov, V. (2022). A typology of material dependencies. Journal of environmental policy \& planning...

Van Der Ploeg, J. D. (1993). Rural sociology and the new agrarian question. A perspective from the Netherlands. Sociologia Ruralis, 33(2), 240-260.

Van der Ploeg, J. (2008). The New Peasantries. London: Earthscan.

Wade, M. R., Geoff M. G., \& S. D. Wratten (2008). Ecological restoration of farmland: progress and prospects. Philosophical Transactions of the Royal Society B: Biological Sciences, 363(1492), 831-47.

Wagner, P. (2001). Modernity, capitalism and critique. Thesis Eleven, 66(1), 1-31.

Wu, X., Wang, S., Fu, B., Feng, X., \& Chen, Y. (2019). Socio-ecological changes on the Loess Plateau of China after Grain to Green Program. Science of the Total Environment, 678, 565-573. 